\title{
Piptadenia stipulacea (Benth.) Ducke Seed Germination in Response to Temperature, Light and Water Stress
}

\author{
Francisco Carlos Barboza Nogueira1*, Maria Luiza Bezerra², Charles Lobo Pinheiro², \\ Selma Freire de Brito², Sebastião Medeiros Filho² \\ ${ }^{1}$ Brazilian Institute of Environment and Renewable Natural Resources-IBAMA, City of Fortaleza, Brazil \\ ${ }^{2}$ Seed Analysis Laboratory (LAS-Laboratório de Análise de Sementes), Plant Science Department, \\ Federal University of Ceará (UFC), Campus of Pici, City of Fortaleza, Brazil \\ Email: ${ }^{\text {fcbarbozanogueira@hotmail.com }}$
}

Received 23 October 2014; revised 22 November 2014; accepted 30 November 2014

Copyright (C) 2014 by authors and Scientific Research Publishing Inc.

This work is licensed under the Creative Commons Attribution International License (CC BY).

http://creativecommons.org/licenses/by/4.0/

(c) (i) Open Access

\begin{abstract}
The current study aimed to investigate the effects of the temperature, light, and water stress on Piptadenia stipulacea seed germination. It assessed germination percentage, speed and average germination time, root and stem length as well as the dry weight of seedlings subjected to the constant temperatures of $20^{\circ} \mathrm{C}, 25^{\circ} \mathrm{C}$ and $30^{\circ} \mathrm{C}$ and alternating temperatures from $20^{\circ} \mathrm{C}$ to $30^{\circ} \mathrm{C}$. A 12-hour photoperiod was established in addition to the following light conditions: white, darkness, red and far red. The experimental design was completely randomized and four replicates of 25 seeds were performed for each treatment. Regarding water stress, seeds were subjected to osmotic potentials of $0,-0.2,-0.4,-0.6,-0.8,-1.0$, and $-1.2 \mathrm{MPa}$, at $30^{\circ} \mathrm{C}$ and $12 \mathrm{~h}$ light/12 $\mathrm{h}$ darkness photoperiods. After they were mixed, 100 seeds were randomly selected for biometric measurement and they were found to be uneven with respect to size and weight. $P$. stipulacea seeds germinated under all tested temperature and light conditions. Germination under water stress occurred up to $-0.8 \mathrm{MPa}$. The conclusion is that there was no germination from $-1.0 \mathrm{MPa}$. The seeds are light-indifferent and germinate at the constant temperatures of $20^{\circ} \mathrm{C}, 25^{\circ} \mathrm{C}$ and $30^{\circ} \mathrm{C}$ and alternating temperatures from $20^{\circ} \mathrm{C}$ to $30^{\circ} \mathrm{C}$.
\end{abstract}

\section{Keywords}

Forest-Tree Seeds, Native Species, Semi-Arid Region, Polyethylene Glycol

\footnotetext{
${ }^{*}$ Corresponding author.
}

How to cite this paper: Nogueira, F.C.B., Bezerra, M.L., Pinheiro, C.L., de Brito, S.F. and Medeiros Filho, S. (2014) Piptadenia stipulacea (Benth.) Ducke Seed Germination in Response to Temperature, Light and Water Stress. American Journal of Plant Sciences, 5, 3796-3804. http://dx.doi.org/10.4236/ajps.2014.526397 


\section{Introduction}

Piptadenia stipulacea (Benth.) Ducke, Fabaceae, is found in “Não me deixes” Farm, a Natural Heritage Private Reserve located in Quixadá County, Ceará State, Brazil, within an area covered by Caatinga vegetation. Its seeds show integumentary dormancy [1], which is a very common phenomenon in seeds from Caatinga area tree species, in the Brazilian Northeast semi-arid region [2]. It is an advantageous evolutionary trait for species that need to ensure their diaspores dispersal in time and space within regions subjected to water restrictions related to drought [3] [4]. The species can also be found in areas disturbed by anthropic activities [5] and its seedlings require light for their initial establishment [6]. These features make P. stipulacea widely used in forest restoration and agroforestry systems.

Once dormancy is broken, the morphologically developed seed requires environmental stimuli such as temperature, light (both quantity and quality) and, above all, water availability for the germination and establishment of new seedlings in a safe environment. In addition to such stimuli, seeds size and vigor are features that must be taken into consideration when one studies native species. Seeds biometry provides important subsidies to differrentiate species from the same genus and it gives information about seeds' health and conservation status [7]-[9].

Investigating light and temperature influence on the seed germination process is the basis for understanding native species ecological and physiological behavior. According to Bewley et al. [10], depending on the species, the seeds can germinate after long or brief exposure to light; germinate in the darkness or with light and darkness periods, whereas others are light-indifferent. In general, the ideal temperature range in which the seed is able to germinate depends on its endogenous limits, thermal characteristics and on the moisture in the place where it has dispersed [11] [12].

In addition to the appropriate temperature and light conditions, water availability is another important abiotic factor responsible for the plant species germination success. Water is responsible for activating different metabolic processes that lead to seed germination, and each species requires a minimum amount of available water in order to germinate [10].

Knowing how abiotic factors such as light, temperature and water affect the $P$. stipulacea seed germination process may contribute to its seeds rational use and to a more efficient seedling production for planting. Knowing seeds biometry allows producers to select those with good size and devoid of physical damage. The current study aimed to investigate the effects of temperature, light and water stress on $P$. stipulacea seed germination.

\section{Material and Methods}

\subsection{Seeds Collection and Storage Place}

P. stipulacea fruits were manually collected from five selected trees in September 2013. The harvesting took place in a Caatinga vegetation area in the Natural Heritage Private Reserve "Não me deixes" Farm (449'34"S, $38^{\circ} 58^{\prime} 9^{\prime \prime} \mathrm{W}$ and $210 \mathrm{~m}$ above current sea level), in Quixadá County, Ceará State, Brazil.

The fruits were dried in an oven $\left(45^{\circ} \mathrm{C} / 3\right.$ days $)$ and processed for seed extraction. After processing, seeds were separated from impurities (part of fruits, leaves, petioles) and from other seeds which were damaged by insects or that were broken. They were then placed in plastic containers and stored (for two months) in a cold chamber at an average temperature of $12^{\circ} \mathrm{C}$ and relative humidity of $55 \%$ until the beginning of the experiments.

The experiments were conducted in the Seed Analysis Laboratory (LAS-Laboratório de Análise de Sementes) from the Plant Science Department, at Federal University of Ceará (UFC). Botanical material containing $P$. stipulacea leaves and fruits was collected for specimen preparation and was deposited at Prisco Bezerra Herbarium-EAC, Federal University of Ceará, under protocol number 054121 (EAC).

\subsection{Biometry and Thousand Seed Weight}

After they were mixed, 100 seeds were randomly selected for individual measurement. Biometric featuring was performed by means of digital caliper $(0.01 \mathrm{~mm})$ through which the following variables were measured: length, width, thickness and weight (in precision scale). The length was measured from the base to the apex and width and thickness were measured on seeds midline. Data were subjected to descriptive statistics in Excel application in order to calculate arithmetic mean, standard deviation, standard error, coefficient of variation and confidence interval for each biometric feature. 
$P$. stipulacea thousand seed weight was calculated in accordance with the Rules for Seed Analysis recommendations [13]. The number of seeds per kilogram was determined from the thousand seed weight results.

\subsection{Temperature and Light}

The dormant seeds [1] were manually scarified with $\mathrm{n}$. 80 sandpaper, opposite to the micropyle, in order to wear the integument. After scarification, they were treated with sodium hypochlorite to avoid fungi attack during germination. The seeds were placed in Becker and carefully and completely immersed in 5\% sodium hypochlorite for 5 minutes. They were then transferred to a fine mesh steel sieve, rinsed in running water and dried with paper towel.

The treated seeds were sown on two sheets of germitest filter paper arranged in $9.50 \mathrm{~cm}$ diameter Petri dishes. The Petri dishes with the sheets of germitest filter paper were previously autoclaved at $120^{\circ} \mathrm{C}$ for 20 minutes. The substrate was moistened with distilled water in the ratio of two and a half times the weight of the paper [13].

Temperature and light effects were checked by using the completely randomized experimental design. Treatments were distributed in $4 \times 4$ factorial arrangement, and subjected to constant temperatures of $20^{\circ} \mathrm{C}, 25^{\circ} \mathrm{C}$ and $30^{\circ} \mathrm{C}$ and alternating temperatures from $20^{\circ} \mathrm{C}$ to $30^{\circ} \mathrm{C}$, under a 12-hour photoperiod and the following light conditions: white, darkness, red, and far red, with four replicates of 25 seeds. During alternating temperatures, the light period corresponded to the higher temperature. As for the white light condition, the Petri dishes were placed in transparent plastic bags to prevent water loss. In the absence of light (darkness), seeds were individually wrapped in aluminum foil and placed inside black plastic bags. For the simulation of red light $(660 \mathrm{~nm})$ and far red light $(730 \mathrm{~nm})$, the method described by Almeida and Mundstock [14] was adopted. The red light was obtained by using two sheets of red cellophane whereas the far red light, was obtained by using two sheets of red cellophane and two sheets of navy blue cellophane as described by Bickford and Dunn [15].

The Petri dishes were placed in a BOD (Biological Oxygen Demand) germination chambers regulated in their constant and alternating temperature regimes. The germinated seeds were daily recorded for 10 days, and the evaluation criterium was the presence of a radicle of at least $2 \mathrm{~mm}$. Security green light was used to count seeds subjected to darkness, red and far red light. During this period, the Petri dishes were carefully remoistened with distilled water when necessary. Finally, the following variables were evaluated:

a) Germination percentage, $\% \mathrm{G}=(N / A) \times 100$, where: $N=$ number of germinated seeds and $A=$ total number of sown seeds.

b) Germination speed index, according to Maguire [16]: GSI $=G_{1} / N_{1}+G_{2} / N_{2}+\ldots+G_{n} / N_{n}$, where: $G_{1}, G_{2}$ and $G_{n}=$ number of germinated seeds in each day and $N_{1}, N_{2} \ldots N_{n}=$ number of days elapsed since the day of sowing.

c) Mean germination time, according to Ranal and Santana [17]: MGT $=\left(\Sigma G_{i} * T_{i}\right) / \Sigma G$, with the results expressed in days, where: $G_{i}=$ number of germinated seeds within a given time interval $T_{i}$, $G=$ number of germinated seeds, $T_{i}=$ days of germination.

d) Length: the length of seedlings root and shoot was measured separately, discarding the cotyledons, with the help of a millimeter ruler.

e) Dry weight: obtained from material placed in paper bags duly identified and dried in the greenhouse at $80^{\circ} \mathrm{C}$, with forced air circulation for $24 \mathrm{~h}$. After this period, the seedlings were weighted in precision scale and the results were expressed as $\mathrm{g} / \mathrm{seedling}$.

\subsection{Water Stress}

The water restriction simulation on P. stipulacea germination under laboratory conditions was tested by means of polyethylene glycol solutions (PEG 6000), which satisfactorily simulates low water potentials. PEG is chemically inert and does not show toxicity to the seeds [18]-[21].

The seeds were placed in Petri dishes (9.50 cm diameter) and the germitest paper substrate was moistened with distilled water (witness) and PEG 6000 solution in different concentrations. The used polyethylene glycol concentrations (PEG 6000) were $-0.2 ;-0.4 ;-0.6 ;-0.8 ;-1.0$ and $-1.2 \mathrm{MPa}$ water potential, obtained for the constant temperature of $30^{\circ} \mathrm{C}$, according to Villela et al. [18]. The experiment was set up in completely randomized design with four replicates of 25 seeds each.

The Petri dishes were kept in germination chamber (BOD) under constant temperature of $30^{\circ} \mathrm{C}$ for a 12-hour photoperiod. The germitest paper substrate and PEG solutions were replaced every 48 hours aiming at main- 
taining the experiment initial conditions. The counts of germinated seed were carried out daily for 14 days, and the germination percentage $(\% \mathrm{G})$ was determined at the end of the experiment.

\subsection{Statistical Analysis}

All the dependent variables were analyzed with respect to normality by using Kolgomorov-Smirnov test, and the homogeneity of variances was analyzed by using the Levene test. After the two criteria were met, the data were subjected to ANOVA, and averages were compared by Tukey's test at $5 \%$ significance level. When they were not met, the data were subjected to non-parametric statistics by the Kruskal-Wallis test and evaluated by nonparametric multiple comparisons at 5\% significance level [22].

\section{Results}

\subsection{Biometric Characteristics}

P. stipulacea seeds are uneven regarding size, and show variation in length (6.71 to $8.67 \mathrm{~mm}$ ), width (4.78 to $6.32 \mathrm{~mm}$ ) and thickness (1.88 to $3.07 \mathrm{~mm}$ ). The unit seed weight ranged from 42.9 to $80.28 \mathrm{mg}$. Seeds descriptive statistics is presented in Table 1. The thousand seed weight was of $44.134 \mathrm{~g}$, which allows inferring that a kilogram of $P$. stipulacea seeds can contain 22,658 seeds.

\subsection{Effect of Temperature and Light on Germination}

Temperature and light quality (white, darkness, red and far red) evaluations for $P$. stipulacea seeds germination percentage $(\% \mathrm{G})$ showed similar means $\left(\mathrm{H}_{(3.15)}=32.96, p=0.0048\right)$. The data presented in Table 2 show that the species germinated regardless the presence and absence of light, both at the constant temperatures of $20^{\circ} \mathrm{C}$, $25^{\circ} \mathrm{C}$ and $30^{\circ} \mathrm{C}$ and at the alternating temperature from $20^{\circ} \mathrm{C}$ to $30^{\circ} \mathrm{C}$.

The ANOVA result for $P$. stipulacea seed germination showed that abiotic factors such as temperature, light and their interactions exerted significant effects for all variables under analysis, with the exception of the light for seedling dry weight (Table 3).

The interaction between light and temperature influenced the germination speed index (GSI). It is possible to see that the highest germination speed index (10.52) occurred at $30^{\circ} \mathrm{C}$ under far red light condition, and the lowest one (4.3) was observed under darkness condition at $20^{\circ} \mathrm{C}$ (Table 4).

There was a significant statistical effect of temperature and light treatments on $P$. stipulacea seeds Mean Germination Time (MGT). The lower MGT was obtained at $30^{\circ} \mathrm{C}$ under red and far red light conditions. The

Table 1. Mean, standard deviation, standard error, coefficient of variation and confidence intervals (CI) relating to biometric measurements (length, width, thickness and weight) in a sample of 100 Piptadenia stipulacea seeds.

\begin{tabular}{cccccc}
\hline Variable & Mean & Standard deviation & Standard error & Coefficient of variation & CI 95\% \\
\hline Length $(\mathrm{mm})$ & 7.7 & 0.51 & 0.05 & 6.65 & $7.69 \pm 0.09$ \\
Width $(\mathrm{mm})$ & 5.44 & 0.35 & 0.04 & 6.4 & $5.44 \pm 0.06$ \\
Thickness $(\mathrm{mm})$ & 2.27 & 0.20 & 0.02 & 8.95 & $2.27 \pm 0.03$ \\
Weight $(\mathrm{mg})$ & 63.48 & 8.34 & 0.83 & 13.14 & $63.48 \pm 1.63$ \\
\hline
\end{tabular}

Table 2. Germination percentage of Piptadenia stipulacea seeds subjected to different temperature and light treatments (mean \pm standard deviation, $n=4$ ).

\begin{tabular}{|c|c|c|c|c|}
\hline \multirow{3}{*}{ Temperature $\left({ }^{\circ} \mathrm{C}\right)$} & \multicolumn{4}{|c|}{ Germination percentage (G\%) } \\
\hline & \multicolumn{4}{|c|}{ Light } \\
\hline & White & Darkness & Red & Far red \\
\hline 20 & $93 \pm 5.03 \mathrm{aA}$ & $86 \pm 2.30 \mathrm{aA}$ & $87 \pm 6.83 \mathrm{aA}$ & $87 \pm 3.82 \mathrm{aA}$ \\
\hline 25 & $91 \pm 3.82 \mathrm{aA}$ & $88 \pm 0.00 \mathrm{aA}$ & $93 \pm 2.00 \mathrm{aA}$ & $93 \pm 2.00 \mathrm{aA}$ \\
\hline 30 & $95 \pm 3.82 \mathrm{aA}$ & $93 \pm 3.82 \mathrm{aA}$ & $95 \pm 2.00 \mathrm{aA}$ & $97 \pm 2.00 \mathrm{aA}$ \\
\hline $20 / 30$ & $93 \pm 3.82 \mathrm{aA}$ & $95 \pm 3.82 \mathrm{aA}$ & $97 \pm 3.82 \mathrm{aA}$ & $95 \pm 5.03 \mathrm{aA}$ \\
\hline
\end{tabular}

Means followed by the same letter do not significantly differ from each other by nonparametric multiple comparisons at 5\% probability. 
Table 3. Results concerning analysis of variance (ANOVA), variance factor (VF), coefficient of variation (CV) and degrees of freedom (Df) for Germination Velocity Index (GVI), Mean Germination Time (MGT), shoot (cm) and root (cm) length and dry weight (root + shoot, g/seedling) of Piptadenia stipulacea seeds and seedlings treated under different temperature and light conditions.

\begin{tabular}{|c|c|c|c|c|c|c|}
\hline \multirow{2}{*}{ Variance factor } & \multicolumn{6}{|c|}{ F values } \\
\hline & Df & GVI & MGT & Shoot & Root & Dry weight \\
\hline Temperature (T) & 3 & $63.97^{* *}$ & $16.09^{* * *}$ & $23.79^{* * *}$ & $0.52^{* *}$ & $0.0247^{* *}$ \\
\hline Light (L) & 3 & $3.71^{* *}$ & $0.58^{* *}$ & $18.54^{* *}$ & $1.17^{* *}$ & $0.0002 \mathrm{~ns}$ \\
\hline $\mathrm{T} \times \mathrm{L}$ & 9 & $2.25^{* *}$ & $0.21^{*}$ & $0.93^{* *}$ & $0.29^{* *}$ & $0.0031^{*}$ \\
\hline Residual & 48 & $0.58^{* * *}$ & $0.10^{* *}$ & $0.29^{* * *}$ & $0.09^{* *}$ & $0.0014^{* *}$ \\
\hline CV (\%) & - & 10.57 & 8.95 & 11.26 & 15.97 & 17.04 \\
\hline
\end{tabular}

${ }^{* *}$ Significant at $1 \%$ probability level by F test; ${ }^{*}$ Significant at $5 \%$ probability level by F test and ns: non-significant.

Table 4. Germination Speed Index of Piptadenia stipulacea seeds subjected to different temperature and light treatments (mean \pm standard deviation, $\mathrm{n}=4$ ).

\begin{tabular}{|c|c|c|c|c|}
\hline \multirow{3}{*}{ Temperature $\left({ }^{\circ} \mathrm{C}\right)$} & \multicolumn{4}{|c|}{ Germination Speed Index (GSI) } \\
\hline & \multicolumn{4}{|c|}{ Light } \\
\hline & White & Darkness & Red & Far red \\
\hline 20 & $4.76 \pm 0.41 \mathrm{aA}$ & $4.3 \pm 0.30 \mathrm{aA}$ & $4.74 \pm 0.39 \mathrm{aA}$ & $4.36 \pm 0.31 \mathrm{aA}$ \\
\hline 25 & $6.89 \pm 0.39 \mathrm{aB}$ & $7.35 \pm 1.37 \mathrm{aB}$ & $7.71 \pm 0.50 \mathrm{aB}$ & $6.72 \pm 0.34 \mathrm{aB}$ \\
\hline 30 & $7.93 \pm 1.02 \mathrm{aB}$ & $8.35 \pm 0.68 \mathrm{aB}$ & $10.25 \pm 1.20 \mathrm{bC}$ & $10.52 \pm 0.51 b D$ \\
\hline $20 / 30$ & $6.89 \pm 0.50 \mathrm{aB}$ & $8.68 \pm 1.60 \mathrm{bB}$ & $8.17 \pm 0.24 \mathrm{abB}$ & $8.47 \pm 0.67 b C$ \\
\hline
\end{tabular}

Means followed by the same lowercase (lines) and uppercase (columns) letters do not significantly differ from each other by the Tukey's test at $5 \%$ probability.

largest MGT was obtained at $20^{\circ} \mathrm{C}$ in all evaluated light conditions (Table 5).

The white light was more efficient in stimulating $P$. stipulacea seedlings' root growth. The highest root length mean occurred at $20^{\circ} \mathrm{C}(2.55 \mathrm{~cm})$ under white light condition, although the other temperatures evaluated under the same light condition were statistically similar (Table 6).

The lowest mean shoot length occurred at $20^{\circ} \mathrm{C}$ in the four evaluated light conditions. There was the highest mean shoot length in all treatments (Table 7).

The dry mass was lower at $20^{\circ} \mathrm{C}$ regarding the four evaluated light conditions. There were small variations in the means obtained from the other treatments (Table 8).

\subsection{Water Stress}

$P$. stipulacea germination percentage was significantly influenced by different treatments with polyethylene glycol (PEG 6000), $(\mathrm{F}=331.29, p<0.001)$. Seed germination was not affected by PEG 6000 concentrations up to $-0.4 \mathrm{MPa}$. However, it was reduced at the concentrations of -0.6 and $-0.8 \mathrm{MPa}$. There was no seed germination at -1.0 and $-1.2 \mathrm{MPa}$ (Figure 1).

\section{Discussion}

Seeds size and weight depended on the year they were produced and on where they were dispersed. Such features can vary in the same individual and within the same functional group [23]. In general, seeds size may vary between five to six orders of magnitude in most habitats [24] [25]. P. stipulacea seeds are classified as small [13]. Water capture is more efficient in small seeds. Large seeds may have difficulty in obtaining water for germination from temporary water supplies because of their low surface to volume ratio [26]. Thus, small seeds germinate first, since they require less water, which is an advantageous feature for Caatinga species, because water availability is restricted to three or four months during the rainy season [27]. P. stipulacea seedling producers can decide for early or late seedlings depending on the seeds size.

$P$. stipulacea seeds germinated under all tested temperature and light conditions. Such fact may reveal the 
Table 5. Mean Germination Time of Piptadenia stipulacea seeds subjected to different temperature and light treatments (mean \pm standard deviation, $\mathrm{n}=4$ ).

\begin{tabular}{ccccc}
\hline & \multicolumn{4}{c}{ Mean Germination Time (MGT) } \\
\cline { 2 - 5 } Temperature $\left({ }^{\circ} \mathrm{C}\right)$ & White & Darkness & Light & \\
\cline { 2 - 5 } 20 & $5.05 \pm 0.42 \mathrm{aB}$ & $5.15 \pm 0.20 \mathrm{aB}$ & $4.79 \pm 0.07 \mathrm{aC}$ & \\
25 & $3.45 \pm 0.12 \mathrm{aA}$ & $3.27 \pm 0.60 \mathrm{aA}$ & $3.15 \pm 0.20 \mathrm{aB}$ & $3.68 \pm 0.14 \mathrm{aB}$ \\
30 & $3.20 \pm 0.58 \mathrm{bA}$ & $2.96 \pm 0.15 \mathrm{abA}$ & $2.45 \pm 0.27 \mathrm{aA}$ & $2.43 \pm 0.15 \mathrm{aA}$ \\
$20 / 30$ & $3.54 \pm 0.33 \mathrm{aA}$ & $2.98 \pm 0.58 \mathrm{aA}$ & $3.00 \pm 0.07 \mathrm{aAB}$ & $2.98 \pm 0.19 \mathrm{aA}$ \\
\hline
\end{tabular}

Means followed by the same lowercase (lines) and uppercase (columns) letters do not significantly differ from each other by the Tukey test at $5 \%$ probability.

Table 6. Piptadenia stipulacea root length subjected to different temperature and light treatments (mean \pm standard deviation, $\mathrm{n}=4)$.

\begin{tabular}{|c|c|c|c|c|}
\hline \multirow{3}{*}{ Temperature $\left({ }^{\circ} \mathrm{C}\right)$} & \multicolumn{4}{|c|}{ Root length (cm) } \\
\hline & \multicolumn{4}{|c|}{ Light } \\
\hline & White & Darkness & Red & Far red \\
\hline 20 & $2.55 \pm 0.27 \mathrm{bA}$ & $1.61 \pm 0.34 \mathrm{aAB}$ & $2.00 \pm 0.38 \mathrm{abAB}$ & $1.69 \pm 0.19 \mathrm{aAB}$ \\
\hline 25 & $2.21 \pm 0.33 \mathrm{bA}$ & $1.58 \pm 0.16 \mathrm{aAB}$ & $1.91 \pm 0.11 \mathrm{abAB}$ & $2.26 \pm 0.30 \mathrm{bB}$ \\
\hline 30 & $2.10 \pm 0.53 \mathrm{bA}$ & $1.61 \pm 0.33 \mathrm{aA}$ & $1.46 \pm 0.35 \mathrm{aA}$ & $1.64 \pm 0.21 \mathrm{abA}$ \\
\hline $20 / 30$ & $2.27 \pm 0.29 \mathrm{bA}$ & $2.08 \pm 0.14 \mathrm{abB}$ & $2.27 \pm 0.24 \mathrm{bB}$ & $1.53 \pm 0.35 \mathrm{aA}$ \\
\hline
\end{tabular}

Means followed by the same lowercase (lines) and uppercase (columns) letters do not significantly differ from each other by the Tukey test at $5 \%$ probability.

Table 7. Piptadenia stipulacea shoot length subjected to different temperature and light treatments (mean \pm standard deviation, $n=4)$.

\begin{tabular}{ccccc}
\hline & & \multicolumn{2}{c}{ Shoot length $(\mathrm{cm})$} \\
\cline { 2 - 5 } Temperature $\left({ }^{\circ} \mathrm{C}\right)$ & White & Darkness & Light & \\
\cline { 2 - 5 } 20 & $2.17 \pm 0.29 \mathrm{bB}$ & $3.56 \pm 0.41 \mathrm{aB}$ & $3.05 \pm 0.44 \mathrm{aC}$ & $3.36 \pm 0.52 \mathrm{aB}$ \\
25 & $4.36 \pm 0.29 \mathrm{bA}$ & $6.37 \pm 1.01 \mathrm{aA}$ & $4.37 \pm 1.10 \mathrm{bB}$ & $6.31 \pm 0.32 \mathrm{aA}$ \\
30 & $4.07 \pm 0.13 \mathrm{cA}$ & $7.23 \pm 0.90 \mathrm{aA}$ & $5.48 \pm 0.34 \mathrm{bA}$ & $6.24 \pm 0.38 \mathrm{abA}$ \\
$20 / 30$ & $3.64 \pm 0.16 \mathrm{cA}$ & $6.89 \pm 0.36 \mathrm{aA}$ & $4.66 \pm 0.23 \mathrm{bAB}$ & $5.50 \pm 0.49 \mathrm{bA}$ \\
\hline
\end{tabular}

Means followed by the same lowercase (lines) and uppercase (columns) letters do not significantly differ from each other by the Tukey test at $5 \%$ probability.

Table 8. Piptadenia stipulacea dry mass subjected to different temperature and light treatments (mean \pm standard deviation, $\mathrm{n}=4)$.

\begin{tabular}{ccccc}
\hline & \multicolumn{4}{c}{ Dry mass } \\
\cline { 2 - 5 } Temperature $\left({ }^{\circ} \mathrm{C}\right)$ & White & Darkness & Red & \\
\cline { 2 - 6 } 20 & $0.16 \pm 0.013 \mathrm{aA}$ & $0.18 \pm 0.02 \mathrm{aA}$ & $0.17 \pm 0.036 \mathrm{aA}$ & $0.17 \pm 0.027 \mathrm{aA}$ \\
25 & $0.25 \pm 0.025 \mathrm{aB}$ & $0.21 \pm 0.035 \mathrm{aA}$ & $0.21 \pm 0.072 \mathrm{aAB}$ & $0.27 \pm 0.02 \mathrm{aB}$ \\
30 & $0.26 \pm 0.036 \mathrm{aB}$ & $0.24 \pm 0.046 \mathrm{aAB}$ & $0.27 \pm 0.044 \mathrm{aB}$ & $0.25 \pm 0.027 \mathrm{aB}$ \\
$20 / 30$ & $0.22 \pm 0.042 \mathrm{aAB}$ & $0.29 \pm 0.022 \mathrm{aB}$ & $0.25 \pm 0.043 \mathrm{aB}$ & $0.22 \pm 0.058 \mathrm{aAB}$ \\
\hline
\end{tabular}

Means followed by the same lowercase (lines) and uppercase (columns) letters do not significantly differ from each other by the Tukey test at $5 \%$ probability.

species ability to adapt itself to thermal fluctuations and natural light levels in the environment in which it is located. According to Guedes et al. [28], this characteristic enables the greater ability by seeds to establish themselves in environments with abiotic constraints (temperature, humidity) as those found in the Brazilian northeastern semiarid region. Myracrodruon urundeuva Allemão and Caesalpinia leiostachhya (Benth.) Ducke seeds, 


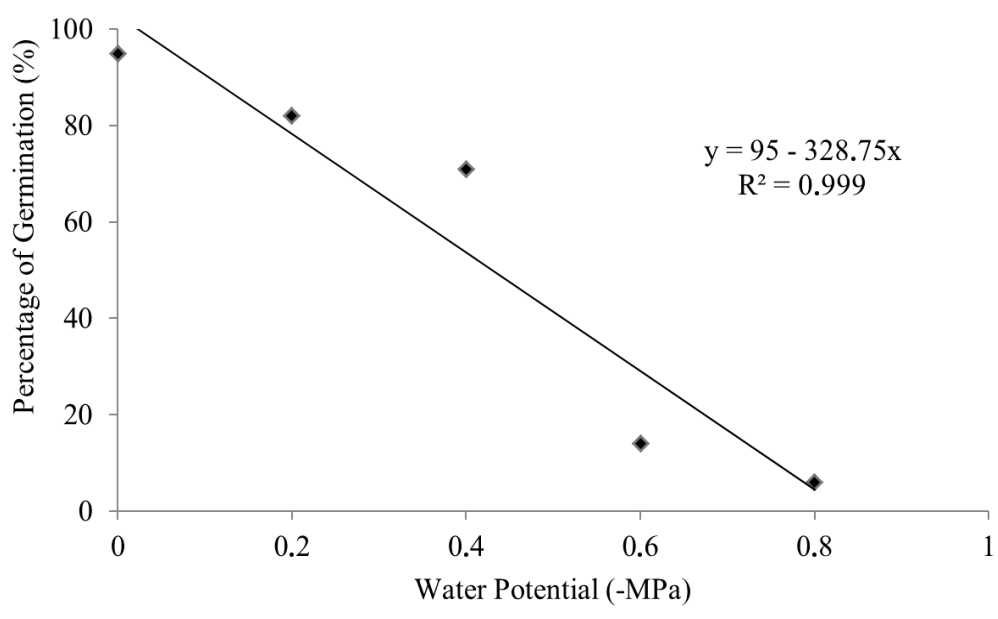

Figure 1. Piptadenia stipulacea seeds germination percentage in different osmotic potentials.

which are common tree species in this region, germinate at the optimal temperatures of $20^{\circ} \mathrm{C}$ and $30^{\circ} \mathrm{C}$, regardless the presence or absence of light [29] [30].

Given the results shown in Table 4, we can observe that the highest germination speed index occurred at $30^{\circ} \mathrm{C}$. There was a trend of increased germination speed index as the temperature increased. Marcos Filho [31] points out that gradual temperature reduction causes a sharp decrease in germination speed index, due to its effects on the absorption and mobilization of the reserves rates. The speed at which seeds germinate is important for the satisfactory seedling establishment in the field. According to Martins et al. [32], when seedlings take a long time to emerge from the soil, they become more vulnerable to adverse environmental conditions. As for seedling market, seed germination and uniformity along with the immediate seedling emergence are attributes that should be taken under consideration in the forest seedlings production.

The lowest mean germination time of $P$. stipulacea seeds was observed at $30^{\circ} \mathrm{C}$ under red and far red light conditions. As this species occurs in Caatinga areas with average temperature of $30^{\circ} \mathrm{C}$, the seeds mean germination time is important for the satisfactory seedling establishment in the field. Another aspect to be considered is the fact that it is used in forest restoration and agroforestry systems. The light had little effect on germination and seedling development was not assessed. In this case, forest seedlings producers should provide appropriate shading in order to ensure rapid and uniform seed germination and subsequent seedling emergence in greenhouses.

In general, the root and shoot average length and dry weight recorded differences among the treatments in the presence of white light. In the laboratory, such light condition simulates the direct sunlight in the field, in which the root tends to grow since it is stimulated by high light intensity. A deep root system allows the most adapted species to occupy degraded areas or areas undergoing environmental restoration projects.

P. stipulacea seeds germination percentage was affected by PEG 6000 concentrations from 0 (control) to -0.8 $\mathrm{MPa}$. The lack of germination in osmotic potentials -1.0 and $-1.2 \mathrm{MPa}$ can be attributed to the very unfavorable water conditions. Under such conditions, seeds avoid germinating as a survival strategy. This way, they can ensure further seedlings development [10].

Seeds from Northeastern semi-arid species show decreased germination when subjected to water stress due to the increased salt concentration up to the critical point, which is typical of each species. Silva et al. [33] corroborated this fact in their study on Cnidoscolus juercifolius Pax and K. Hoffm. seeds, in which germination was zero at $-0.9 \mathrm{MPa}$.

\section{Conclusion}

$P$. stipulacea seeds were found to be uneven with respect to size and weight. $P$. stipulacea seeds germinated under water stress occurred up to $-0.8 \mathrm{MPa}$ and seeds are light-indifferent and germinate at the constant temperatures of $20^{\circ} \mathrm{C}, 25^{\circ} \mathrm{C}$ and $30^{\circ} \mathrm{C}$ and alternating temperatures from $20^{\circ} \mathrm{C}$ to $30^{\circ} \mathrm{C}$. 


\section{References}

[1] Farias, R.M., Freitas, R.M.O., Nogueira, N.W. and Dombroski, J.L.D. (2013) Overcoming of Dormancy of Piptadenia stipulacea Seeds. Revista de Ciências Agrárias, 56, 160-165. (In Portuguese) http://dx.doi.org/10.4322/rca.2013.024

[2] Barbosa, H.A., Huete, A.R. and Baethgen, W.E. (2006) A 20-Year Study of NDVI Variability over the Northeast Region of Brazil. Journal of Arid Environments, 67, 288-307. http://dx.doi.org/10.1016/j.jaridenv.2006.02.022

[3] Reis, A.C.S. (1976) Clima da Caatinga. Anais da Academia Brasileira de Ciências, 48, 329-335.

[4] Sampaio, E.V.S.B. (1995) Overview of the Brazilian Caatinga. In: Bullock, S.H., Mooney, H.A and Medina, E., Eds., Seasonally Dry Tropical Forests, University Press, Cambridge, 35-63.

[5] Pereira, I.M., Andrade, L.A., Costa, J.R.M. and Dias, J.M. (2001) Natural Regeneration in a Caatinga Fragment under Different Disturbance Levels. Acta Botânica Brasílica, 15, 413-426. (In Portuguese) http://dx.doi.org/10.1590/S0102-33062001000300010

[6] Ferreia, W.N., Zandavalli, R.B., Bezerra, A.M.E. and Medeiros Filho, S. (2012) Early Growth of Piptadenia stipulacea (Benth.) Ducke and Anadenanthera colubrina (Vell.) Brenan var. cebil (Griseb.) Altshul (Fabaceae) Exposed to Different Levels of Shade. Acta Botanica Brasilica, 26, 408-414. (in Portuguese) http://dx.doi.org/10.1590/S0102-33062012000200016

[7] Cruz, E.D., Martins, F.O. and Carvalho, J.E.U. (2001) Fruit and Seed Biometry and Germination of Jatoba-Curuba (Hymenaea intermedia Ducke, Leguminosae-Caesalpinioideae). Revista Brasileira de Botânica, 24, 161-165. http://dx.doi.org/10.1590/S0100-84042001000200005 (in Portuguese)

[8] Castellani, E.D., Damião Filho, C.F., Aguiar, I.B. and Paula, R.C. (2008) Fruit and Seed Morphology of Solanum L. Forest Species. Revista Brasileira de Sementes, 30, 102-113. (In Portuguese) http://dx.doi.org/10.1590/S0101-31222008000100014

[9] Fenner, M. (1993) Seed Ecology. Champman e Hall, London.

[10] Bewley, J.D., Bradford, K.J., Hilhorst, H.W.M. and Nonogaki, H. (2012) Seeds: Physiology of Development, Germination and Dormancy. Springer, New York.

[11] Blank, R.R. and Young, J.A. (1992) Influence of Matric Potential and Substrate Characteristics on Germination of Nezpar Indian Ricegrass. Journal of Range Management, 45, 205-209. http://dx.doi.org/10.2307/4002785 https://journals.uair.arizona.edu/index.php/jrm/article/view/8715/8327

[12] Qi, M.Q. and Redmann, R.E. (1993) Seed Germination and Seedling Survival of $C_{3}$ and $C_{4}$ Grass under Water Stress. Journal of Arid Environments, 24, 277-285. http://dx.doi.org/10.1006/jare.1993.1024 http://www.sciencedirect.com/science/article/pii/S0140196383710244

[13] Brazil (2009) Rules for Seed Analysis. Ministério da Agricultura, Pecuária e Abastecimento. Secretaria de Defesa Agropecuária, Brasília. (In Portuguese)

[14] Almeida, M.L. and Mundstock, C.M. (2001) Light Quality Affects Tillering on Wheat When Grown under Competition. Ciência Rural, 31, 401-408. (In Portuguese) http://dx.doi.org/10.1590/S0103-84782001000300006

[15] Bickford, E.D. and Dunn, S. (1978) Lighting for Plant Growth. The Kent State University Press, London.

[16] Maguire, J.D. (1962) Speed of Germination-Aid in Selection and Evaluation for Seedling Emergence and Vigor. Crop Science, 2, 176-177. http://dx.doi.org/10.2135/cropsci1962.0011183X000200020033x

[17] Ranal, M.A. and Santana, D.G. (2006) How and Why to Measure the Germination Process? Brazilian Journal of Botany, 29, 1-11. http://www.scielo.br/scielo.php?script=sci arttext\&pid=S0100-84042006000100002 http://dx.doi.org/10.1590/S0100-84042006000100002

[18] Michel, B.E. and Kaufmann, M.R. (1973) The Osmotic Potential of Polyethylene Glycol 6000. Plant Physiology, 51, 914-916. http://dx.doi.org/10.1104/pp.51.5.914

[19] Villela, F.A., Doni-Filho, L. and Sequeira, E.L. (1991) Tabela de Potencial Osmótico em Função da Concentração de Polietileno glicol 6000 e da Temperatura. Pesquisa Agropecuária Brasileira, 26, 1957-1968.

[20] Hardegree, S.P. and Emmerich, W.E. (1994) Seed Germination Response to Polyethylene Glycol Solution Depth. Seed Science and Technology, 22, 1-7. http://naldc.nal.usda.gov/naldc/download.xhtml?id=6952\&content=PDF

[21] Gorai, M., Tlig, T. and Neffati, M. (2009) Influence of Water Stress on Seed Germination Characteristics in Invasive Diplotaxis harra (Forssk.) Boiss (Brassicaceae) in Arid Zone of Tunisia. Journal of Phytology, 1, 249-254.

[22] Siegel, S. and Castellan, J. (1988) Non Parametric Statistics for the Behavioral Sciences. MacGraw Hill Int., New York.

[23] Commes, D.A. and Grubb, P.J. (2003) Colonization, Tolerance, Competition and Seed-Size Variation within Functional Groups. TRENS in Ecology and Evolution, 18, 283-291. http://dx.doi.org/10.1016/S0169-5347(03)00072-7

[24] Leishman, M.R., Wright, I.J., Moles, A.T. and Westoby, M. (2000) The Evolutionary Ecology of Seed Size. In: Fenner, 
M., Ed., Seeds_-The Ecology of Regeneration in Plant Communities, CAB International, Wallingford, 31-58.

[25] Jurado, E., Estrada, E. and Molès, A. (2001) Characterizing Plant Attributes with Particular Emphasis on Seeds in Tamaulipan Thornscrub in Semi-Arid México. Journal of Arid Environments, 48, 309-321. http://www.sciencedirect.com/science/article/pii/S0140196300907626 http://dx.doi.org/10.1006/jare.2000.0762

[26] Harper, J.L., Lovell, P.H. and Moore, K.G. (1970) The Shapes and Size of Seeds. Annual Review of Ecology and Systematics, 1, 327-356. http://dx.doi.org/10.1146/annurev.es.01.110170.001551

[27] Leal, I.R., Tabarelli, M. and Silva, J.M.C. (2003) Ecologia e Conservação da Caatinga. Universitária da UFPE, Recife.

[28] Guedes, R.S., Alves, E.U., Gonçalves, E.P., Braga Jr., J.M., Viana, J.S. and Colares, P.N.Q. (2010) Temperatures and Substrates for Germination and Vigor Test of Amburana cearensis (Allemão) A.C. Smith Seeds. Revista Árvore, 34, 57-64. (In Portuguese) http://dx.doi.org/10.1590/S0100-67622010000100007

[29] Silva, L.M.M., Rorigues, T.J.D. and Aguiar, I.B. (2002) The Effect of Light and Temperature on the Germination of Myracrodruon urundeuva Allemão. Revista Árvore, 26, 691-697. (In Portuguese) http://dx.doi.org/10.1590/S0100-67622002000600006

[30] Biruel, R.P., Aguiar, I.B. and Paula, R.C. (2007) Germination of Caesalpinia leiostachya (Benth.) Ducke. Seeds under Different Conditions of Storage, Chemical Scarification, Temperature and Light. Revista Brasileira de Sementes, 29, 151-159. (In Portuguese) http://dx.doi.org/10.1590/S0101-31222007000300018

[31] Marcos Filho, J. (2005) Fisiologia de Sementes de Plantas Cultivadas. FEALQ, Piracicaba.

[32] Martins, C.C., Nakagawa, J., Bovi, M.L.A. and Stanguerlim, H. (2000) Influence of Red-Palmito (Euterpe espiritosantensis Fernandes) Seed Weight in the Percentage and Germination Speed. Revista Brasileira de Sementes, 22, 47-33. (In Portuguese) http://www.abrates.org.br/revista/artigos/2000/v22n1/artigo08.pdf

[33] Silva, L.M.M., Aguiar, I.B., Morais, D.L. and Viégas, R.A. (2005) Water Stress and Osmotic Conditioning on Physiological Quality of Cnidosculus juercifolius. Revista Brasileira de Engenharia Agrícola e Ambiental, 9, 66-72. (In Portuguese) http://dx.doi.org/10.1590/S1415-43662005000100010 
Scientific Research Publishing (SCIRP) is one of the largest Open Access journal publishers. It is currently publishing more than 200 open access, online, peer-reviewed journals covering a wide range of academic disciplines. SCIRP serves the worldwide academic communities and contributes to the progress and application of science with its publication.

Other selected journals from SCIRP are listed as below. Submit your manuscript to us via either submit@scirp.org or Online Submission Portal.
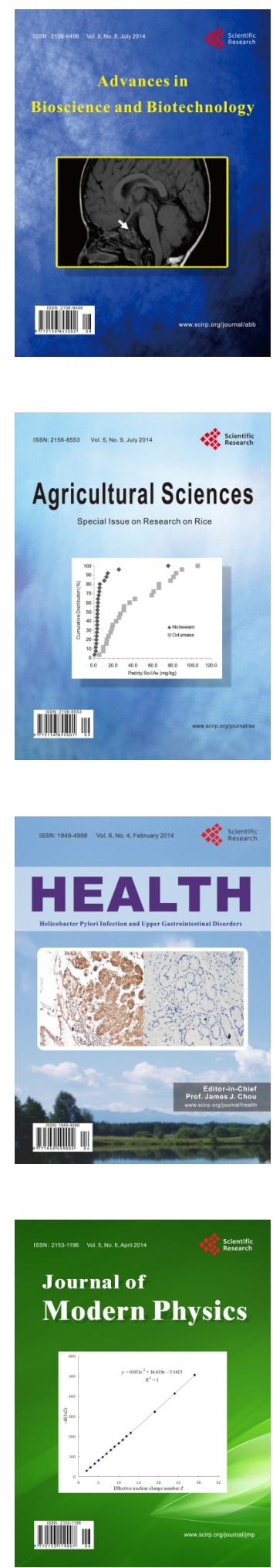
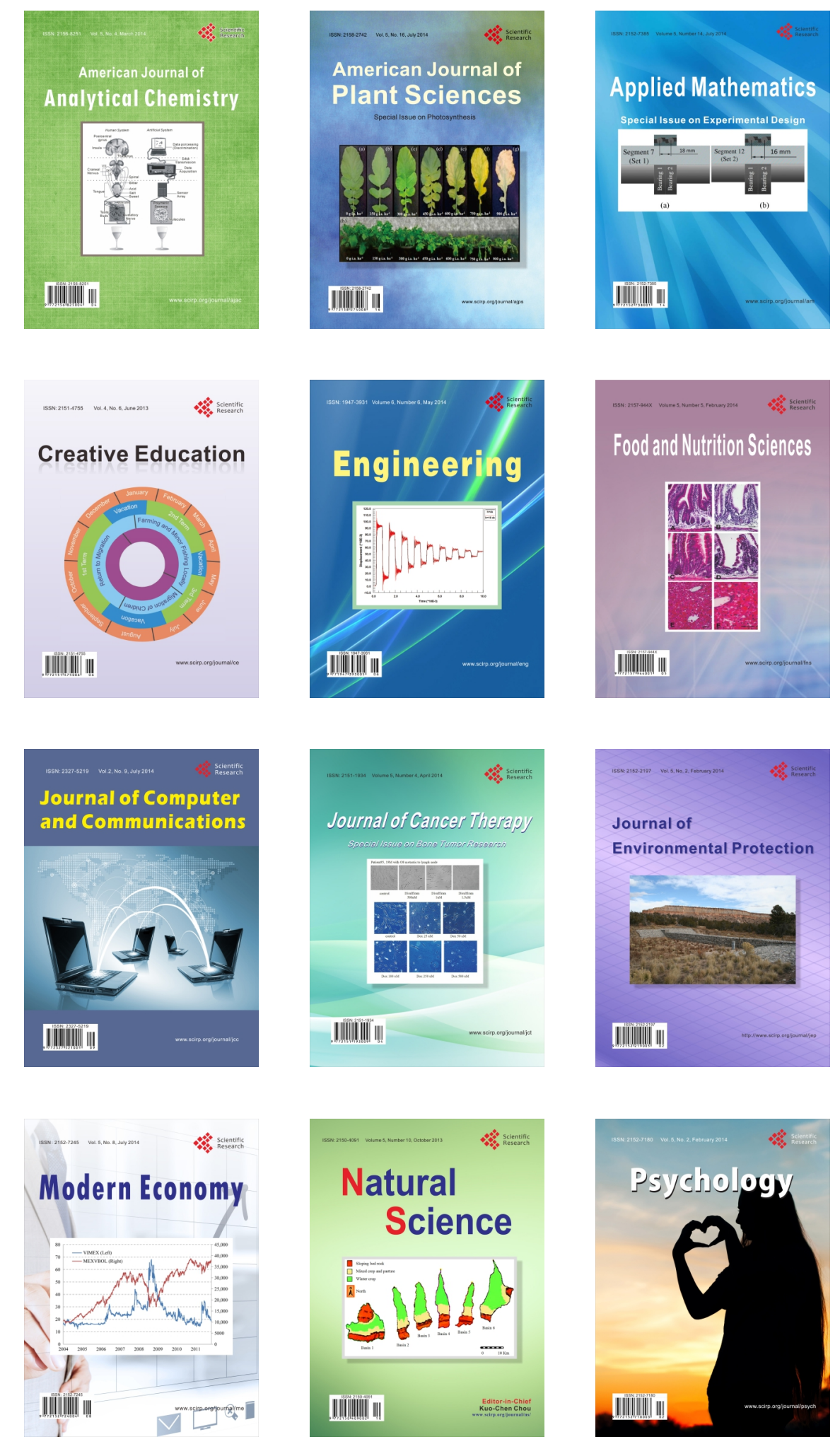